sto

\title{
SEJARAH MASUKNYA DA'WAH ISLAM DI INDONESIA
}

\author{
ABDUL KADIR BADJUBER \\ kadir@stidnatsir.ac.id \\ STID Mohammad Natsir, Indonesia
}

\begin{abstract}
ABSTRAK
Tujuan penelitian ini untuk mengetahui sejarah masuknya da'wah Islam di Indonesia. Metode yang digunakan kajian literature. Hasil dari penelitian ini menunjukkan bahwa sebagian sarjana-sarjana Islam ahli sejarah itu menyebutkan bahwa pembawa Islam ke Nusantara ini di sampaikan oleh para dai, atau para sudagar Islam yang disertai dengan para dai. Ini yang menjadi keteguhan pandangan dari Haji Agus Salim, KH. Saefuddin Zuhri, Hamka dan yang lainnya. Sarjana-sarjana dan intelektual Islam ahli sejarah ini menjelaskan pula bahwa Islam berkembang di Nusantara dengan damai tanpa kekerasan. Sehingga mendapat sambutan yang baik dari masyarakat setempat, dan berkembang dengan cepat. Yang masuk dan memeluk Islam di Nusantara ketika Islam datang itu tidaknya rakyat jelata, tetapi juga dari kaum keraton dan bangsawan. Setelah lama Islam bersentuhan dengan penduduk Indonesia, lama kelamaan karena faktor Islam sendiri dan juga, pembawanya. Maka Islam lambat laun menjadi agama mayoritas bangsa Indonesia.
\end{abstract}

Kata kunci: sejarah, da'wah, Indonesia

\section{PENDAHULUAN}

Kajian tentang sejarah Islam di Indonesia adalah bahasan yang menarik untuk dikaji dan ditelusuri. Tetapi melacak sejarah masuknya Islam ke Nusantara bukan hal mudah. Sudah banyak literature yang membahas tentang sejarah Islam di Indonesia ini.

Namun, tidak sedikit pula data-data sejarah Islam di Indonesia yang masih bertupu pada Literatur sarjana-sarjana Barat. Tentunya data ini masih mengundang pertanyaan dan kegamangan berbagai pihak terutama ahli-ahli sejarah Islam. Beberapa sarjana dan intelektual Islam Indonesia, sebutlah misalnya, Haji Agus Salim, KH. Saefuddin Zuhri, 
Taufik Abdullah ${ }^{1}$ dan sejarawan Islam lainnya, berkesimpulan sama. Mereka masih mempertanyakan data yang valid tentang masuknya Islam ke Indonesia.

Inilah yang disebut oleh Haji Agus Salim dengan istilah, "Seolah cerita yang tidak memuaskan". Sehingga tidak sedikit sarjana-sarjana muslim seolah ingin memunculkan sebuah rekontruksi sejarah Islam di Indonesia. Disebabkan oleh ketidakpuasan mengenai bukti-bukti dan sumber-sumber sejarah masuknya Islam ke Nusantara. Ketidak puasan para sejarawan Islam Indonesia ini adalah sesuatu yang wajar adanya. Dan kenyataan ini tentunya mendorong mereka untuk terus mengadakan pengkajian, penelusuran dan penelitian secara khusus tentang sejarah masuknya Islam di Indonesia.

Syarif Hidayat menyebutkan, bahwa masuknya Islam ke kawasan Nusantara sejak lama telah menjadi kajian khusus sejarah di Indonesia. Berbagai seminar telah dilakukan untuk mendapatkan kepastian kapan dan siapa yang pertama memperkenalkan di kawasan Nusantara. Diantara seminar yang membahas dan melakukan berbagai kajian sejarah tentang masuk dan berkembangnya Islam di Nusantara telah menghasilkan kesimpulan-kesimpulan penting.

Seminar yang diprakarsai oleh H. Mohammad Said yang diselenggarakan di Medan pada 17-20 Maret 1963 juga, seminar yang diselenggarakan oleh MUI Daerah khusus Istimewa Propensi Aceh, di Banda Aceh tanggal 25-30 September 1980. Serta seminar internasional tentang sejarah Islam di Rantau Kualasimpang Aceh Timur 25-30 September 1980. Waktu itu, seminar ini dihadiri oleh menteri Agama RI. H. Alamsyah Ratu Prawiranegara, dalam kesempatan itu Alamsyah, menyampaikan sambutannya yang berjudul "Penulisan sejarah di Indonesia".

Dalam seminar itu Alamsyah Prawiranegara, menegaskan bahwa seminar di Medan yang diselenggarakan pada tahun 1963 itu, merupakan langkah awal yang penting dalam upaya menggali menemukan kembali fakta sejarah masuknya Islam di Indonesia. Hasil seminar itu merupakan koreksi atas kesalahan-kesalahan yang dilakukan oleh penulis-penulis sejarah sebelumnya, khususnya versi dari para orientalis. ${ }^{2}$

${ }^{1}$ Lihat Taufik Abdullah, Pemikiran Islam di Nusantara dalam Perspektif Sejarah, Prisma, 3 Maret 1991. hal 18.

${ }^{2}$ Lihat I. Syarief Hidayat, Sejarah Masuknya Islam di Indonesia, makalah dari seminar Historiografi Islam Indonesia. 9-11 Desember 2007, Balitbang Lektur Keagamaan DEPAG RI., 
Melihat kenyataan ini, jauh-jauh hari - pada tahun 1962 Haji Agus Salim (1884 - 1954) sudah menulis risalah kecil tentang Islam di Indonesia. Dalam karya yang berjudul Riwayat Kedatangan Islam di Indonesia, Haji Agus Salim, menyebutkan, kedatangan Islam di Nusantara menurut Ahli-ahli Islam di Barat kira-kira pada abad ke-12 Masehi. Mula-mula datangnya Islam di Indonesia karena pengaruh pedagangpedagang dan orang-orang yang menyebarkan ilmu dari tanah Hindustan ${ }^{3}$. Kemudian beristrikan wanita setempat, beranak pinang, berjual-beli dengan masyarakat setempat, lama kelamaan Islam berkembang di Indonesia. Begitu, kira-kira menurut sudut pandang orang-orang Barat tentang perkembangan Islam di Indonesia, tulis Haji Agus Salim. ${ }^{4}$

Lebih jauh Haji Agus Salim menyebutkan, "Menurut pendapat orang-orang ahli ketimuran (orentalisten - Belanda) bangsa Barat, kedatangan orang Islam kemari ada dekat 600 tahun kemudian daripada masa pengutusan Nabi Muhammad SAW. yaitu kira-kira 1200 hitungan Miladiyah. Berjejak agama Islam di sini ialah karena pengaruh orangorang dagang dan orang-orang pelajaran (kooplieden en geluk zoekers) dari tanah Hindustan. Orang itu berbini, beranak ditempat-tempat kediaman di sini dan berhubungan berjual beli dengan orang-orang isi negeri. Lama kelamaan dengan karena pertalian-pertalian yang tumbuh karena itu, berkembanglah agama Islam, sehingga akhirnya sebagian besar beragama Islam. Begitu kisahnya, jika kita ambil dari karangan bangsa Barat".

Data inilah yang menjadi keraguan Haji Agus Salim. riteratur yang disampaikan oleh sarjana-sarjana Barat itu, menurutnya, 'nyata sekali pikiran itu salahnya'. ${ }^{6}$ Tidak hanya Agus Salim yang berpandangan begitu tapi juga, KH. Saefuddin Zuhri, Ali Hasyimi dan sejarwan lainnya. Bahkan dengan tegas, Hasyimi mengecam keras pandangan kaum orientalis karena mereka telah memutarbalikan fakta sejarah Islam di Indonesia. Mereka tidak mau mengakui bahwa Islam datang ke Nusantara pada abad pertama Hijriyah.

Ada memang, orientalisme atau sarjana-sarjana Barat yang mengakui bahwa Islam masuk dan tersebar di Asia Tenggara dan di kepulauan Indonesia sejak abad ke-7 atau 8. Tetapi, perlu dicatat jumlahnya hanya sedikit sekali.

\footnotetext{
${ }^{3}$ Mungkin yang dimaksud adalah Ghujarat, India.

${ }^{4}$ Hadji Agus Salim, Riwajat Kedatangan Islam Di Indonesia, (Jakarta: 1962, Tintamas), hal 10.

${ }^{5}$ Hadji Agus Salim, Riwajat Kedatangan Islam Di Indonesia, Ibid, hal 10.

${ }^{6}$ Ibid, hal 10.
} 
Bahasan selanjutnya akan menjelaskan sejarah kedatangan Islam ke Nusantara dari beberapa sumber yang berasal dari sejumlah sejarawan Islam Indonesia. Juga, dari penelitian para sarjana-sarjana Barat (orientalis). Tentunya data-data itu menjadi bahan penelusuran dan penelitian kita bersama.

\section{HASIL DAN DISKUSI}

\section{Sejarah Masuknya Islam di Indonesia}

Menurut Syaefuddin Zuhri, hampir semua ahli sejarah dan pengamat sejarah merasakan betapa amat sukarnya memperoleh kepastian tentang hari, tanggal dan tahun kapankan Islam datang ke Indonesia pertama kali. Letak kesulitannya adalah berpangkal pada bahan penyelidikan yang ditemukan atau catatan-catatan yang harus ditelaah itu bercampur baur sedemikian rupa sehingga memerlukan penyelidikan lagi. Mana yang mengandung nilai dan fakta sejarah, mana yang hanya berupa dongeng.

Ada buku-buku sejarah yang biasanya dianggap mengandung 'nilai ilmiyah' akan tetapi bersumber pada penulisan kaum orientalis Barat, atau ditulis oleh orang-orang yang berpendidikan Barat, yang kadangkala mempergunakan kaca mata Barat.

Memang, kita harus berlaku adil dalam menilai suatu kebenaran darimana pun datangnya. Kita sering menemukan nilai-nilai sejarah yang ilmiah dari catatan atau kisah-kisah yang hidup dikalangan masyaratakat tetapi kita sering diapriorikan sebagai dongeng atau legenda. Tetapi kita juga sering menemukan nilai sejarah yang tidak boleh diabaikan sungguhpun ditulis oleh kaum orientalis Barat. Untuk itu memerlukan penelitian yang cermat dan adil.

Mengenai sebagian kaum orientalis Barat, kita tidak boleh mengabaikan faktor-faktor yang meliputi alam kejiwaan mereka serta latar belakang penulisannya. Suatu ketika mereka menulis sejarah Islam sambil jiwanya diliputi oleh sikap membenci Islam. Dan suatu ketika sedang dalam kebimbangan setelah melihat sendiri bagaimana Islam menjadi faktor kenyataan yang tidak bisa dibantah. Tetapi juga banyak dikalangan mereka yang dapat membedakan mana yang mengandung faktor obyektif positif dan mana yang negatif. Sekalipun demikian baik pula manakala memperhatikan juga pertimbangan lain, misalnya bahwa penulisan mereka didorong oleh profesi atau pekerjaan dan mata

7 KH. Saefuddin Zuhri, Sejarah Kebangkitan Islam dan Perkembangannya di Indonesia, (Bandung: PT. Al-Ma'arif, 1983, Cet. Ke-3), hal 169. 
pencaharian mereka sebagai penulis dan pengumpul fakta-fakta sejarah. Sekalipun tidak ada hubungannya dengan faktor kepercayaan terhadap apa yang mereka lakukan. Sebagai orang yang bukan pemeluk Islam tentulah mereka tidak terikat untuk mempercayainya. Tidak sedikit dari mereka yang melakukan pendekatan dalam menemukan fakta sejarah dan kebenaran sekalipun pada mulanya hati mereka tidak percaya. Akan tetapi tidak jarang terjadi bahwa bathinnya ikut bicara sehingga dalam penulisaannya disisipkan pendapat pribadinya yang mengunsuri hasil karyanya itu. Tentu saja hasilnya tidak akan obyektif. ${ }^{8}$ Tidak sedikit para orientalis yang bersikap seperti itu. Itulah gambaran bathin orientalis Barat dalam menulis sejarah Islam di Indonesia.

Inilah menurut Saefuddin Zuhri, sebab mengapa tidak mudahnya untuk memperoleh kepastian hari dan tanggal kapankah Islam pertama kali datang ke Indonesia bila semata-mata hanya bersandar pada penemuan orientalis Barat. Umat Islam menggunakan hasil karya para penulis sejarah yang bersikap adil disamping berpedoman pada fakta-fakta sejarah yang dimiliki dari nenek moyangnya berupa catatan atau naskah, justru mereka itu bukan saja orang-orang yang mencintai sejarah akan tetapi juga, yang turut membuat sejarah.

Karena tidak banyaknya jejak yang bisa diambil dalam menelusuri sejarah masuknya Islam ke Indonesia ada beberapa pertanyaan yang bisa diajukan untuk menelusuri kedatangan Islam ke Nusantara. Pertanyaan-pertanyaan itu adalah dari mana Islam datang ? Siapa yang membawanya dan kapan kedatangannya?.

Ada beberapa teori yang menjelaskan tentang masuknya Islam ke Indonesia yang sampai hari ini masih dibahas oleh sarjana Barat dan juga sarjana Islam. Setidaknya ada tiga teori yang menjelaskan tentang masuknya Islam ke Timur Jauh termasuk ke Nusantara.

Pertama, seperti disampaikan oleh Ali Hasyimi, yang dikutif oleh Syarif Hidayat, teori yang menyebutkan bahwa Islam pertama kali masuk ke Nusantara melalui India pada abad ke-13. Teori ini pertama kali diusung oleh Snouch Hurgronje yang menyatakan Islam datang ke Indonesia dari wilayah-wilayah di anak benua India. Tempat-tempat seperti Gujarat, Bengali dan Malabar disebut sebagai asal masuknya Islam di Nusantara. Teori ini lahir sekitar tahun 1883 M. Selain diperkenalkan oleh Snouck Hurgronye, juga oleh orientalis lain

\footnotetext{
${ }^{8}$ Saefuddin Zuhri, Ibid, hal 170.

${ }^{9}$ Saefuddin Zuhri, Ibid hal 174.
}

77 | Bina Ummat | Vol 4 | No. 1 | 2021 
diantaranya adalah RA. Ken, Dr. Gonda, Marrison, NH. Krom, CAO. Van Nieuwenbuizen, Harry J. Benda $a^{10}$ dan yang lainnya.

Teori ini berdasarkan pada suatu pandangan bahwa pada abad tersebut terdapat hubungan perniagaan yang sangat kuat antara India dengan gugusan pulau-pulau Melayu, sehingga dengan demikian saudagar-saudagar muslim dari Gujarat memasuki pelabuhan-pelabuhan di tanah Melayu dan Nusantara pada umumnya, mereka memperkenalkan Islam sekaligus mendakwahkannya. ${ }^{11}$

Dalam L'arabie et les Indes Neerlandaises, Chistian Snouck Hurgronye (1857-1936), ${ }^{12}$ mengatakan bahwa teori tersebut didasarkan pada pengamatan tidak terlihatnya peran dan nilai-nilai Arab pada masamasa awal, yakni pada abad ke-12 atau 13. Snouck juga mengatakan, teorinya didukung dengan hubungan yang sudah terjalin lama antara wilayah Nusantara dengan daratan India.

Sebetulnya, teori ini dimunculkan pertama kali oleh Pijnappel, seorang Sarjana dari Universitas Leiden. Namun, nama Snouck Hurgronje yang paling besar memasarkan teori Gujarat ini. Salah satu alasannya karena Snouck dipandang sebagai sosok yang mendalami Islam. Teori ini diikuti dan dikembangkan oleh banyak sarjana Barat lainnya. ${ }^{13}$ Diantaranya adalah N.H. Krom dan Van Den Breg. Bahkan secara khusus $V$ an Den Berg menulis sebuah buku mengenai koloni keturunan Arab di Nusantara. ${ }^{14}$ Pandangan ini merupakan pandangan yang sudah lama berkembang dikalangan sejarawan Indonesia. Pendapat inilah yang kemudian mendapat bantahan dan sanggahan dari sejarawan muslim Indonesia.

Diantaranya, oleh Haji Agus Salim, Hamka, Saefuddin Zuhri dan ahli sejarah Islam Indonesia lainnya. Menurut Agus Salim Data yang disampaikan oleh sarjana-sarjana Barat itu, menurutnya, 'nyata sekali pikiran itu salahnya' ${ }^{15}$. Menurut Haji Agus Salim, bahwa pada abad ke-8 M. atau abad ke-2 H. sudah ada perniagaan Bangsa Islam di tanah

\footnotetext{
${ }^{10}$ Lihat Masroer Ch. Jb., The History Of Java, (Jakarta: Ar-Ruzz, 2004, Cet. 4) hal 37.

${ }^{11}$ Syarif Hidayat Of. Cit. hal 2.

${ }^{12}$ Sebagai perbandingan tentang siapa sosok Snouck Hurgronje, silahkan membaca bukunya Prof. HM. Rasyidi, Islam dan Indonesia Di zaman Modern dan P.SJ. Van Koningsveld, Snouck Hurgronje dan Islam (Jakarta: Griyamukti Pusaka, 1989).

${ }^{13}$ Heri Nurdi, Risalah Islam Nusantara, Dalam topik Sejarah Emas Muslim Indonesia, Sabili,No.9 th.X 2003.

${ }^{14}$ Lihat LWC. Van Den Berg, Hadramaut dan koloni Arab di Nusantara (Jakarta: INIS, 1989), hal 67. H. Endang Saifuddin Anshari, Wawasan Islam Pokok-pokok pikiran tentang paradigma dan Sistem Islam, (Jakarta: 2004, GIP, Cet. 1), hal 195.

${ }^{15}$ Hadji Agus Salim, Riwajat Kedatangan Islam Di Indonesia, Ibid, hal 10.
} 
Tiongkok, dipesisir sebelah timur, pada tahun 758 M. dan pada satu abad sesudahnya didaratan Tiongkok sudah ada orang Islam di Kraton, bahkan sudah teratur kedudukannya. Bahkan, Agus Salim menyebutkan, sudah dikepalai oleh seorang pembesar yang berkedudukan sebagai qadbi dan di situ sudah dilaksanakan shalat jum'at dan qadhi bertindak sebagai Imam Jum'at. ${ }^{16}$

Teori lain juga, menyebutkan bahwa Islam datang ke Nuasantara pertama kali dibawa oleh orang Persia. Dan teori ini menyakini bahwa Islam masuk wilayah Nusantara pada abad ke -13 M. dan wilayah pertama yang di singgahi adalah Samudera Pasai. Yang melandasi teori ini adalah adanya kesamaan budaya yang dimiliki oleh beberapa kelompok masyarakat Islam dengan penduduk Persia. Misalnya, peringatan 10 Muharram yang dijadikan sebagai peringatan wafatnya Hasan dan Husein. Disebutkan pula bahwa dasar lainnya adalah adanya beberapa serapan yang dinyakini datang dari Iran. Seperti, kalimat jabar dari zabar, Jer dari ze-er dan beberapa kalimat serapan lainnya. ${ }^{17}$

Sumber yang menyatakan bahwa Islam datang pertama kali ke Indonesia itu adalah mulanya dari Persia (Iran). Menurut Saefuddin Zuhri, sumber-sumber itu berasal dari orientalis Barat. Salah satu dalilnya adalah dihubungkan dengan nama kerajaan Islam di Indonesia yang pertama yaitu, Kerajaan Pase. Nama Pase itu diambil dari nama 'Persi' sebagai suatu tanda hormat dan untuk mengingati nama negeri Persi dari mana Islam mula-mula datang ke Indonesia.

Tetapi, ahli-ahli sejarah bangsa Indonesia sendiri membantahnya. Nama pase diambil dari nama 'pasir' menurut logat dan lidah orang Aceh, Sesuai dengan letak kerajaan Pase yang berada di pantai pulau Sumatra yang berpasir itu, persis terletak di daerah Aceh. Saudara-saudara kita suku Aceh pada umumnya hampir tidak dapat mengucapkan huruf " $\mathrm{r}$ " yang mati diakhiran kata. Mereka mengucapkan 'pase' untuk pasir. Seperti juga, 'aye' untuk 'air'.

Di zaman penjajahan Balanda saudara-saudara kita di Aceh tidak sudi mengucapkan Belanda dengan 'Belanda' tetapi si 'kape' untuk maksud si kafir. Maka untuk mengenang tumpah darah pantai Aceh yang bersejarah, mereka menamakan kerajan Islam yang pertama di Indonesia yang terletak di bumi Aceh dengan sebutan 'Kerajaan Pese' sebagai sanjungan dan kebanggaan nasionalnya ketika itu dengan sikap

\footnotetext{
${ }^{16}$ Hadji Agus Salim, hal 11-12.

${ }^{17}$ Heri Nurdi, Of. Cit., hal 10.
}

79 | Bina Ummat | Vol 4 | No. 1 | 2021 
mereka yang amat bersahaja; kerajaan Pasir dengan lidah Aceh 'Kerajaan Pase'. ${ }^{18}$

Bahkan, Saefuddin Zuhri menegaskan, teori yang menyatakan bahwa Islam pertama kali datang ke Indonesia melalui Parsi (Iran), agaknya untuk membuat kesimpulan bahwa Islam pertama kali datang ke negeri kita beraliran Syiah. Asumsi atau dugaan demikian tidak bisa dipertanggung jawabkan. ${ }^{19}$

$\underline{\text { Kedua }}$, teori ini menyatakan bahwa Islam datang ke Nusantara pada awal abad ke-7 M. atau pada 1 Hijriyah. Menyatakan bahwa Islam masuk ke kawasan Nusantara melalui daratan dan lautan Cina. Seorang ahli kepurbakalaan Uka Tjandrasasmita, menyatakan bahwa salah satu sumber sejarah yang sampai saat ini seringkali dihubungkan dengan kedatangan pertama orang-orang muslim di Indonesia ialah sekelumit berita Cina yang berasal dari hikayat dari dinasti Tang yang menceritakan tentang orang-orang Ta' Shih yang mengurungkan niatnya untuk menyerang kerajaan Ho Ling yang diperintah oleh Ratu Sima (674 M.). Berdasarkan sumber ini beberapa ahli sejarah berpendapat bahwa pada abad pertama Hijriyah atau abad ke-7 M. orang-orang muslim dari negeri Arab sudah datang di Indonesia yang pemukimannya terletak di Sumatera.

Sementara itu sumber Jepang sekitar 748 M. memberitakan tentang banyaknya kapal orang-orang Tashih Kuo dan orang-orang Posse berlabuh di Khanfu (kanton). W.P. Groeneveldt memperkirakan bahwa tashih adalah orang-orang Arab yang pemukimannya di Sumatera Barat. Sementara W. Wheatley memperkirakan terletak di Kuala Brang dekat Trengganu. Jalur perjalanan da'wah Islam oleh saudagar-saudagar Arab adalah dari Aden menyusur pesisir pantai India Barat dan selatan. Atau melalui perjalanan darat dari khurasan melalui hutan, padang pasir Gobi, Sangtu, Nansyau, Kanton, menyebrangi laut Cina Selatan, masuk kawasan Melayu melalui pesisir pantai timur semenanjung Tanah Melayu. ${ }^{20}$ Sarjana-sarjana lain yang menyebutkan bahwa Islam datang pada abad pertama Hijriyah atau abad ke-7 dan 8 Masehi diantaranya adalah M. Zainal Arifin Abbas, Sayed Alwi bin Thahir al-Hadad, HM. Zainuddin, Djuned Parinduri dan T.W. Arnold. ${ }^{21}$

Ketiga. Teori yang menyebutkan bahwa Islam datang ke Nusantara langsung dari tanah Arab. Dan waktu kedatanganya pun

${ }^{18}$ KH. Saefuddin Zuhri, Sejarah Kebangkitan Islam dan Perkembangannya di Indonesia, (Bandung: 1981, PT. al-Maarif Bandung, cet. ke-3), hal 174-175.

${ }^{19}$ KH. Saefuddin Zuhri, Ibid, hal 175.

${ }^{20}$ Syarif Hidayat Of. Cit. hal 3.

${ }^{21}$ Endang Saifuddin Anshari, hal 195. 
bukan pada abad ke-12 atau 13 M. sebagaimana pandangan orientalis Barat. Tetapi pada abad pertama Hijriyah atau pada permulaan abad ke$7 \mathrm{M}$. Bahkan, dengan tegas Hamka menyebut bahwa yang pertama kali menyebarkan Islam di Nusantara adalah langsung dari Mekah. ${ }^{22}$ Juga, Madinah. ${ }^{23}$ Hamka pun membantah yang menyebutkan kalau Islam yang datang ke Indonesia itu 'bukan dari tangan kedua' atau dari orang Islam India dan Parsi. ${ }^{24}$

Pada teori yang terakhir ini penyebaran dilakukan oleh para mubaligh yang langsung datang dari tanah Arab. Atau bisa juga para saudagar muslim itu disertai oleh para mubaligh yang akan menyebarkan Islam di Nusantara. ${ }^{25}$ Dan teori yang menyebutkan bahwa Islam masuk langsung dari jazirah Arab itu melalui jalur pelayaran Aden dan Hadramaut langsung ke gugusan pulau-pulau Melayu.

Kalau ada sumber sejarah yang menyebutkan bahwa Islam masuk pertama kali dari Ghujarat, India. Maka menurut Saefuddin Zuhri, mengartikannya harus demikian, yaitu; Mubaligh-mubaligh itu datang dari Mekah - Madinah sebagian besar lewat Yaman dan sekitarnya. Lalu singgah beberapa waktu di Ghujarat, sebelum meneruskan perjalanan mereka ke Timur (Indonesia, Malaysia dan filipina). Kemungkinan itu sangat besar karena perjalanan itu ditempuh dengan perahu-perahu layar yang mengarungi Samudra Indonesia yang luas dan amat jauh. ${ }^{26}$

Amatlah masuk akal, menurut Saefuddin Zuhri, bahwa bangsa Arab dalam hubungannya dengan dengan sejarah masuknya Islam ke Indonesia itu memegang peran kepemimpinan, jadi bukan orang-orang India sekalipun Mubaligh. Ditambah ketika itu umat Islam di India merupakan minoritas dibanding dengan pemeluk agama Hindu. Tentulah para mubaligh Islam India lebih mengutamakan untuk berdakwah di negerinya sendiri, daripada berdakwah ke Indonesia. Dan Zuhri pun, menambahkan, berbeda dengan mubaligh-mubaligh bangsa

\footnotetext{
${ }^{22}$ Prof. Dr. Hamka, Sejarah Umat Islam, (Singapura: Pustaka Nasional, 2005, Cet. Ke-5) hal 673-680.

${ }^{23}$ KH. Saefuddin Zuhri, Of. Cit., hal 177.

${ }^{24}$ Hamka, Ibid, hal 673.

${ }^{25}$ Lihat H.A. Mu'in Umar (editor), Penulisan Sejarah Islam di Indonesia dalam Sorotan, (Yogyakarta: 1985, Dua Dimensi) hal 23. Lihat pula H. Endang Saifuddin Anshari, Wawasan Islam Pokok-pokok Pikiran Tentang Paradigma dan Sistem Islam, Of. Cit., hal 196.

26 Saefuddin Zuhri, Sejarah Kebangkitan Islam dan Perkembangannya di Indonesia, Of. Cit., hal 177.
} 
Arab, mereka sengaja melakukan dakwah Islam (sambil berdagang) baik menuju sasaran India (Gujarat) maupun Indonesia. ${ }^{27}$

Pandangan Hamka dan Agus Salim yang menyebutkan bahwa Islam masuk ke Nusantara pada awal abad pertama Hijriyah atau pada abad ke-7 M, itu sesuai dengan hasil seminar di Medan pada tahun 1963. menurut Saefuddin Zuhri pada seminar yang berlangsung empat hari itu dari tanggal 17-20 Maret 1963 yang dihadiri oleh puluhan para ahli sejarah. Dan pada akhirnya seminar mengambil kesimpulan sebagai berikut:

1. Bahwa menurut sumber-sumber yang kita ketahui, Islam untuk pertama kalinya telah masuk ke Indonesia pada abad pertama hijriyah atau pada abad ke 7 atau 8 Masehi dan langsung dari Arab.

2. Bahwa daerah yang pertama didatangi oleh Islam ialah pesisir Sumatera. Dan setelah terbentuknya masyarakat Islam, maka raja Islam yang pertama berada di Aceh.

3. Dalam pengislaman selanjutnya, Orang-orang Indonesia ikut aktif mengambil bagian.

4. Mubaligh-mubaligh Islam yang pertama itu selain, sebagai penyiar Islam juga sebagai saudagar.

5. Penyiaran Islam yang dilakukan di Indonesia itu menggunakan cara yang damai.

6. Bahwa kedatangan Islam ke Indonesia itu membawa kecerdasan dan peradaban yang tinggi dalam membentuk kepribadian bangsa Indonesia. ${ }^{28}$ Demikian kesimpulan yang dihasilkan dalam seminar di Medan itu.

\section{Proses Islamisasi Di Indonesia}

Dalam Ensiklopedi Islam disebutkan bahwa Islamisasi Nusantara sejak abad ke-7 diduga kuat oleh para musafir dan pedagang muslim dari Arab. Walaupun disebutkan juga berasal dari Persia, dan India (Gujarat)

27 Saefuddin Zuhri, Sejarah Kebangkitan Islam dan Perkembangannya di Indonesia, Ibid., hal 178.

28 Saefuddin Zuhri, Sejarah Kebangkitan Islam dan Perkembangannya di Indonesia, Ibid, hal 176. Lihat pula H. Endang Saifuddin Anshari, Wawasan Islam Pokok-pokok Pikiran Tentang Paradigma dan Sistem Islam, hal 196. lihat pula Prof. Tk. Ismail Jakub, Sejarah Islam di Indonesia, (Jakarta: 1973, Widjaya, cet. Ke-3), hal 18. 
- walaupun ada yang membantahnya- telah memperkenalkan Islam di Nusantara. Hal ini dimungkinkan karena sejak abad ke-5 Samudera Hindia telah menjadi kawasan yang berbahasa Arab dan jalan dagang Teluk Persia-Tiongkok yang terus berlanjut sampai beberapa abad kemudian. Pada abad ke-10 Malaka telah menjadi pelabuhan penting bagi pedagang muslim di Asia. Islam datang ke negeri ini dengan jalan damai. Para mubaligh melangsungkan perkawinan dengan penduduk setempat dan Islam berkembang secara turun menurun. J.C. vam Leur dalam bukunya Indonesia Trade and Society (Den Haag: W. van Hoeve Publishers Ltd., 1967) seperti di kutip Ensiklopedi Islam, berpendapat bahwa karena yang membawanya adalah para pedagang maka Agama Islam lebih menarik daripada agama penduduk sebelumnya, Hindu dan Budha.

Pada abad ke-11 telah ditemukan pemukiman-pemukiman Islam di kota-kota pantai Nusantara. Hal ini antara lain terbukti dengan ditemukannya batu nisan dengan nama Fatimah binti Maimun (w.475 H/1082 M) di Leran, Gresik; demikian pula makam Sultan Malikush Shaleh (1270-1297), raja pertama Kerajaan Samudera Pasai di Aceh, dan makam wanita Islam, Tuhar Amisuri $(602 \mathrm{H})$ di Barus, pantai barat Pulau Sumatra.

Pada abad ke-13 kerajaan-kerajaan Islam telah dikenal secara pasti, misalnya Kerajaan Samudera Pasai di Aceh Utara. Kerajaan Samudera Pasai dikunjungi Ibnu Batutah pada tahun 1325. Ternyata ia menemukan Sultan Muhammad Malik Zahir (1927-1326), putra Sultan Malikush Shaleh, sebagai seorang yang alim dan saleh. Di istana dan masjid yang dibangunnya sering diadakan pertemuan dan diskusi mengenai masalah-masalah keagamaan dengan para ulama terkemuka yang berdatangan dari pusat-pusat peradaban Islam.

Masa selanjutnya, abad ke-13 sampai abad ke-17, merupakan fase berdirinya pusat-pusat kekuasaan Islam di Nusantara dan merupakan masa kemajuan Islam. Pada masa inilah Aceh, Demak, Giri, Ternate/Tidore, Gowa dan Tallo (di Makasar [kini: Ujung pandang]) muncul sebagai pusat kekuasaan, perdagangan, dan pengajian Islam, dan berdiri sebagai kesultanan Islam. Dari pusat-pusat inilah Islam tersebar ke seluruh Nusantara. Kelompok yang berperan penting dalam penyebaran Islam adalah para wali, terutama yang dikenal di Jawa dengan istilah Wali Songo ${ }^{29}$ (Wali Sembilan), ulama, dan para mubaligh yang telah dibina di pusat-pusat pendidikan Islam seperti pesantren dan surau. Pusat-pusat tersebut telah berfungsi sebagai tempat pendidikan

\footnotetext{
${ }^{29}$ Walaupun masih dipersoalkan keberadaannya para sejarawan Islam. Lihat bahasan selanjutnya.
}

83 | Bina Ummat | Vol 4 | No. 1 | 2021 
dan tempat kaum cendekiawan, pusat penyebaran Islam, dan media komunikasi serta informasi. Pada sisi lain, peran pedagang dan penguasa kerajaan-kerajaan Islam itu sangat besar dalam penyebaran agama islam.

Sejak abad ke-13 pengembangan Islam telah terlihat dengan jelas. Dari Samudera Pasai dan Aceh Darussalam, Islam antara lain menyebar ke Minangkabau, dari Minangkabau ke Gowa dan Tallo di Sulawesi Selatan, dan dari Gowa dan Tallo menyebar lagi terus ke Bima dan Kutai. Dari Demak, Cirebon, dan Giri, Islam menyebar ke Lombok, Sumbawa, Ternate/Tidore, dan Hitu; dari Ternate menyebar lagi ke Sulawesi Utara, Irian Jaya, dan Nusa Tenggara Timur.

Agama Islam tersebar dengan daya tarik dakwahnya melalui perdagangan. Sejak abad ke-17 dapat dikatakan bahwa Islam telah menyebar ke seluruh Nusantara melalui berbagai saluran seperti perdagangan, perkawinan, birokrasi pemerintahan, pendidikan (pesantren), dan lain-lain. Namun demikian, sampai abad tersebut belum ada organisasi Islam yang teratur yang mengutamakan dakwah ${ }^{30}$.

Pada masa kedatangan dan penyebaran Islam di Nusantara, pada saat itu sudah terdapat kerajaan-kerajaan yang bercorak Hindu dan Budha. Di Sumatera terdapat kerajaan Sriwijaya dan Melayu. Di Jawa terdapat Majapahit dan Sunda Pajajaran, di kalimantan terdapat kerajaan Daha dan Kutai.

Agama Islam yang datang ke Indonesia mendapat perhatian khusus dari kebanyakan rakyat yang telah memeluk agama Hindu. Agama Islam dipandang oleh rakyat yang semula menganut agama Hindu lebih baik, karena tidak mengenal kasta, Islam tidak mengenal golongan dalam masyarakat. Daya penarik Islam bagi pedagang yang hidup di bawah kekuasaan raja-raja Indonesia - Hindu agaknya ditemukan pada orang kecil, Islam memberi suatu persamaan bagi pribadinya sebagai anggota masyarakat muslim. Sedangkan menurut alam fikiran orang Hindu ia hanyalah suatu makhluk yang lebih rendah derajatnya dari pada kasta-kasta lain. Di dalam Islam ia merasa dirinya sama atau bahkan, lebih tinggi daripada orang-orang yang bukan Islam. Meskipun dalam struktur masyarakat ia masih menempati kedudukan bawahan.

Proses Islamisasi di Indonesia terjadi dan dipermudah karena adanya dua pihak, yakni orang-orang muslim pendatang yang mengajarkan Islam dan golongan masyrakat Indonesia sendiri yang menerimanya. Lebih-lebih cara-cara yang ditempuh oleh orang-orang muslim dalam menyebarkan agama Islam disesuaikan dengan kondisi

\footnotetext{
${ }^{30}$ Ensiklopedi Islam, hal 215
} 
sosial budaya mereka yang telah ada. Dengan demikian dalam taraf permulaan Islamisasi dilakukan dengan saling pengertian akan kebutuhan dan kondisinya.

Dalam perkembangan selanjutnya, golongan penerima dapat menjadi pembawa atau penyebar Islam untuk orang lain di luar golongan atau daerahnya. Dalam hal ini kontinuitas antara penerima dan penyebar terus terpelihara dan dimungkinkan sebagai sistem pembinaan calaon-calon pemberi ajaran tersebut. Biasanya santri-santri yang pandai dan telah lama belajar seluk beluk agama Islam di suatu tempat, kemudian kembali ke daerahnya, menjadi pembawa dan penyebar ajaran yang telah mereka peroleh. Mereka kemudian mendirikan pondokpondok pesantren. Dan pondok pesantren merupakan lembaga yang penting dalam penyebaran agama Islam. ${ }^{31}$

Agama Islam juga membawa perubahan sosial dan budaya yakni memperhalus dan memperkembangkan budaya Indonesia. Penyesuaian antar dapat dengan syari'ah diberbagai daerah di Indonesia selalu terjadi, meskipun kadang-kadang dalam taraf permulaan mengalami proses pertentangan dalam masyarakat. Meskipun demikian, proses Islamisasi diberbagai tempat di Indonesia dilakukan dengan cara yang dapat diterima oleh rakyat setempat. Sehingga kehidupan keagamaan masyrakat pada umumnya menunjukan unsur-unsur campuran antara Islam dengan kepercayaan sebelumnya. Hal itu terjadi karena Indonesia telah sejak lama terdapat agama Hindu atau Budha dan kepercayaan animisme. $^{32}$

Buya hamka dengan panjang lebar menggambarkan tentang kepercayaan bangsa Indonesia sebelum Islam datang. Sebagian masyarakat masih percaya kepada bentuk-bentuk kepercayaan tertentu. Seperti misalnya pemujaan kepada Dewi Sri atau Sang Hyang Sri, yang dianggap sebagai dewi kesuburan tanah. ${ }^{33}$

Umumnya kedatangan Islam di Nusantara dan penyebaran kepada golongan bangsawan maupun rakyat dengan cara damai. Dan kedatangan Islam diberbagai daerah Indonesia tidaklah bersamaan. Demikian pula kerajaan-kerajaan dan daerah yang didatanginya mempunyai situasi politik dan sosial yang budaya yang berlainan. Pada

\footnotetext{
${ }^{31}$ Marwati Djoened Poesponegoro, Sejarah Nasional Indonesia, Jilid III, (Jakarta: Balai Pustaka) 1984, hal 173. sebagaimana dikutif Dadan Wildan, Pentas Persis dalam sejarah Islam Indonesia, hal 4.

${ }^{32}$ Ibid hal 4.

${ }^{33}$ Prof. Dr. Hamka, Sejarah Umat Islam, (Singapura: Pustaka Nasional2005, Cet. Ke-5) hal 6658-659.
} 
waktu kerajaan Sriwijaya mengembangkan kekuasaannya sekitar abad ke-7 dan 8, selat Malaka sudah dilalui oleh pedagang-pedagang muslim dalam pelayarannya ke negeri-negeri di Asia Tenggara dan Asia Timur.

\section{Cepat Tersiarnya Islam Di Indonesia}

Banyak faktor yang menjadi penyebab cepatnya Islam diterima oleh penduduk Indonesia. Secara ringkas dijelaskan oleh Endang Saefuddin Anshari dan Tengku Ismail Jakub, menurutnya, sebelum Islam masuk ke Nusantara, agama Hindu dan Budha telah berkembang luas di Nusantara ini, di samping masih menganut animisme dan dinamisme. Kedua agama itu kian hari kian memudar cahayanya, dan kedudukan akhir sepenuhnya diganti oleh agama Islam, yang kemudian hari menjadi kenyakinan mayoritas rakyat Indonesia. Sebab-sebab semakin pesat dan cepat tersiarnya Islam di Indonesia antara lain adalah sebagai berikut:

1. Terutama sekali adalah karena faktor agama Islam (akidah, syari'ah, dan akhlak Islam) sendiri yang lebih banyak 'berbicara' kepada segenap lapisan masyarakat Indonesia. Apakah itu penguasa, pedagang, petani dan yang lainnya.

2. Faktor para dua't Islam lebih banyak yang terdiri para saudagar yang taraf kebudayaannya sudah tinggi, telah berhasil membawakan al-Islam dengan segala kebijaksaan, kemahiran dan keterampilan.

3. Ajaran Islam tentang dakwah untuk menyampaikan ajaran di seluruh pelosok bumi telah menjadikan segenap kaum muslimin menjadi umat dakwah.

4. Baik agama Hindu maupun Budha pada umumnya dipeluk oleh orang-orang keraton yang pada saat tersebarnya Islam antara raja yang satu dengan yang lainnya terlibat dalam perselisihan.

5. Pernikahan antara para penyebar Islam dan orang-orang yang baru di-Islam-kan melahirkan generasi pelanjut yang menganut dan menyebarkan Islam. ${ }^{34}$

\footnotetext{
${ }^{34}$ Lihat Endang Saifuddin Anshari, Wawasan Islam Pokok-pokok Pikiran Tentang Paradigma dan Sistem Islam, Ibid, hal 197.
} 
6. Agama Hindu percaya kepada yang ghoib. Agama Islam pun percaya kepada yang ghoib. Mudahlah bagi mereka memahami ajaran-ajaran Islam yang menarik hati mereka. ${ }^{35}$

Cepat tersiarnya Islam di Nusantara yang dinilai kalangan begitu cepat dan meratanya sampai kepelosok Nusantara, itu disebabkan ketika pemimpin atau sultan atau juga raja mereka masuk Islam masuk maka rakyat atau masyarakat yang menjadi bawahannya kemudian pula menyatakan memeluk Islam.

Selain faktor perkawinan antara penyiar Islam dengan masyarakat setempat. Juga faktor masuknya para pemimpin kerajaan atau kesultanan yang berimbas berduyun-dusunnya masyarakat atau rakyat yang kemudian memeluk Islam. Inilah yang terjadi dalam kenyataan sejarah mengapa begitu cepatnya Islam masuk ke Indonesia.

\section{Wali Songo}

Terlepas dari pro dan kontra tentang adanya Wali Songo. Ensiklopedi Islam menyebutkan bahwa Wali Songo atau sembilan ulama merupakan pelopor dan pejuang islamisasi di pulau Jawa pada abad ke15 atau masa ke sultanan Demak. Dalam bahasa Arab 'wali' antara lain berarti pembela, teman dekat, dan pemimpin. Dalam pemakaiannya wali diartikan sebagai orang yang dekat dengan Allah SWT.

Sedangkan kata "Songo" (Jawa) berarti sembilan. Maka Wali Songo secara umum diartikan sebagai sembilan wali yang dianggap telah dekat dengan Allah SWT, terus-menerus beribadah kepada-Nya, serta memiliki kekeramatan dan kemampuan-kemampuan lain di luar kebiasaan manusia ${ }^{36}$.

Dalam penyiaran Islam di Jawa, Wali Songo dianggap sebagai kepala kelompok dari sejumlah besar mubaligh Islam yang mengadakan dakwah di daerah-daerah yang belum memeluk agama Islam. Mereka adalah : (1) Sunan Gresik, (2) Sunan Ampel, (3) Sunan Bonang, (4) Sunan Giri, (5) Sunan Drajat, (6) Sunan Kalijaga, (7) Sunan Kudus, (8) Sunan Muria, dan (9) Sunan Gunung Jati.

Namun masih terdapat perbedaan pendapat di kalangan ahli sejarah tentang nama-nama mereka yang termasuk kelompok sembilan wali tersebut. Secara singkat, apa dan siapa para Wali Songo tersebut adalah sebagai berikut;

\footnotetext{
${ }^{35}$ Prof. Tk. Ismail Jakub, Sejarah Islam di Indonesia, (Jakarta: 1973, Widjaya, cet. Ke-3), hal 17.

${ }^{36}$ Istilah-istilah ini yang dipersoalkan oleh para ulama-ulama Islam.
} 
Sunan Gresik Maulana Malik Ibrahim, Sunan Ampel (Campa, Aceh , 1401-Tuban, Jawa Timur, 1481). Nama aslinya Raden Rahmat. Ia adalah putra Maulana Malik Ibrahim dari istrinya yang bernama Dewi Candrawulan.

Sunan Ampel adalah penerus cita-cita serta perjuangan Maulana Malik Ibrahim, dan terkenal sebagai perencana pertama kerajaan Islam di Jawa. Ia memulai aktivitasnya dengan mendirikan pesantren di Ampel Denta, dekat Surabaya, sehingga ia dikenal sebagai pembina pondok pesantren pertama di Ampel Denta, dekat Surabaya, sehingga ia dikenal sebagai pembina pondok pesantren pertama di Jawa Timur. Di pesantren inilah Sunan Ampel mendidik para pemuda Islam untuk menjadi tenaga dai yang akan disebar ke seluruh pulau Jawa. Di antara pemuda yang dididik itu tercatat antara lain Raden paku, yang kemudian terkenal dengan nama Sunan Giri, Raden Fatah yang kemudian menjadi sultan pertama kesultanan Islam di Bintoro, Demak, Raden Makdum Ibrahim (putra Sunan Ampel sendiri) yang kemudian dikenal dengan Sunan Bonang, Syaripuddin yang kemudian dikenal dengan Sunan Drajat, Maulana Ishak yang pernah diutus ke daerah Blambangan untuk mengislamkan rakyat di sana, dan banyak lagi mubaligh yang mempunyai andil besar dalam islamisasi Pulau Jawa.

\begin{tabular}{|c|c|c|c|c|}
\hline \multicolumn{5}{|c|}{ PENYEBAR AGAMA ISLAM DI P. JAWA (WALI SONGO) } \\
\hline & NAMA & GELAR & $\begin{array}{l}\text { TAHUN } \\
\text { WAFAT }\end{array}$ & $\begin{array}{l}\text { TEMPAT } \\
\text { MAKAM }\end{array}$ \\
\hline 1 & $\begin{array}{l}\text { Maulana Malik } \\
\text { Ibrahim }\end{array}$ & $\begin{array}{l}\text { Sunan } \\
\text { Gresik }\end{array}$ & $\begin{array}{r}2 \text { Rabiulawal } \\
\text { 822/8 April } \\
1419\end{array}$ & $\begin{array}{l}\text { Perkuburan } \\
\text { Gapura Wetan, } \\
\text { Gresik }\end{array}$ \\
\hline 2 & R. Rahmat & $\begin{array}{l}\text { Sunan } \\
\text { Ampel }\end{array}$ & 1481 & $\begin{array}{l}\text { Masjid Ampel, } \\
\text { Surabaya }\end{array}$ \\
\hline 3 & $\begin{array}{l}\text { R. Paku (R. } \\
\text { Ainul Yakin) }\end{array}$ & $\begin{array}{l}\text { Sunan } \\
\text { Giri }\end{array}$ & awal abad ke-16 & $\begin{array}{l}\text { Bukit Giri, } \\
\text { Gresik }\end{array}$ \\
\hline 4 & $\begin{array}{l}\text { R. Maulana } \\
\text { Makhdum } \\
\text { Ibrahim }\end{array}$ & $\begin{array}{l}\text { Sunan } \\
\text { Bonang }\end{array}$ & 1525 & Tuban \\
\hline 5 & $\begin{array}{l}\text { R. Kosim } \\
\text { Syarifuddin }\end{array}$ & $\begin{array}{l}\text { Sunan } \\
\text { Drajat }\end{array}$ & $\begin{array}{r}\text { Pertengahan } \\
\text { abad ke-16 }\end{array}$ & Sedayu, Gresik \\
\hline 6 & $\begin{array}{l}\text { Syarif } \\
\text { Hidayatullah }\end{array}$ & $\begin{array}{l}\text { Sunan } \\
\text { Gunung } \\
\text { Jati }\end{array}$ & 1570 & $\begin{array}{l}\text { Gunung Jati, } \\
\text { desa Astana, } \\
\text { Cuirebon }\end{array}$ \\
\hline
\end{tabular}




\begin{tabular}{|c|c|c|c|c|}
\hline 7 & R. Ja'far Sadiq & $\begin{array}{l}\text { Sunan } \\
\text { Kudus }\end{array}$ & 1550 & Kdus \\
\hline 8 & R. Mas Syahid & $\begin{array}{l}\text { Sunan } \\
\text { Kalijaga }\end{array}$ & $\begin{array}{r}\text { pertengahan } \\
\text { abad ke-15 }\end{array}$ & $\begin{array}{l}\text { Kadilangu } \\
\text { Demak }\end{array}$ \\
\hline 9 & $\begin{array}{l}\text { R. Mas (R. } \\
\text { Prawoto) }\end{array}$ & $\begin{array}{l}\text { Sunan } \\
\text { Muria }\end{array}$ & abad ke-16 & $\begin{array}{l}\text { Bukit Muria, } \\
\text { Jepara }\end{array}$ \\
\hline
\end{tabular}

Sumber: Ensiklopedi Islam

Menurut Babad Diponegoro, sebagaimana dikutif Ensiklopedi Islam, Sunan Ampel sangat berpengaruh di kalangan istana Majapahit, bahkan istrinya pun berasal dari kalangan istana. Raden Fatah, putra Prabu Brawijaya, raja Majapahit, menjadi murid Sunan Ampel. Dekatnya Sunan Ampel dengan kalangan istana membuat penyebaran Islam di daerah kekuasaan Majapahit, khususnya di pantai utara Pulau Jawa, tidak mendapat hambatan yang berarti, bahkan mendapat izin dari penguasa kerajaan.

Sunan Ampel tercatat sebagai perancang kerajaan Islam pertama di Pulau Jawa dengan ibu kota di Bintoro, Demak. Dialah yang mengangkat Raden Fatah sebagai sultan pertama Demak, yang dipandangan punya jasa paling besar dalam meletakkan peran politik umat Islam di Nusantara.

Di samping itu Sunan Ampel juga ikut mendirikan Masjid Agung Demak pada tahun 1479 bersama wali-wali yang lain. Ketika mendirikan masjid tersebut, para wali mengadakan pembagian tugas. Sunan Ampel diserahi tugas membuat salah satu dari saka guru (tiang katu raksasa) yang kemudian dipasang di bagian tenggara. Tiga tiang besar yang lain dikerjakan oleh Sunan Kalijaga untuk tiang sebelah timur laut (bukan berupa tiang utuh, tetapi berupa beberapa balok yang diikat menjadi satu yang disebut "saka tatal"), Sunan Bonang untuk tiang sebelah barat laut, Sunan Gunung Jati untuk tiang sebelah barat daya, sementara bagian-bagian lain masjid dikerjakan oleh para wali yang lain.

Pada awal islamisasi Pulau Jawa, Sunan Ampel menginginkan agar masyarakat menganut keyakinan yang murni. Ia tidak setuju bahwa kebiasaan masyarakat Jawa seperti kenduri, selamatan, sesaji, dan sebagainya tetap hidup dalam sistem sosio-kultural masyarakat yang telah memeluk agama Islam. Namun wali-wali yang lain berpendapat bahwa untuk sementara semua kebiasaan tersebut harus dibiarkan karena masyarakat sulit meninggalkannya secara serentak. Akhirnya Sunan Ampel mentoleransinya. Hal tersebut terlihat dari persetujuannya 
ketika Sunan Kalijaga, dalam usahanya menarik penganut Hindu dan Budha, mengusulkan agar adat-istiadat Jawa itulah yang diberi warna Islam. Sunan Ampel setuju walaupun ia tetap mengkhawatirkan adat dan upacara-upacara tersebut kelak menjadi bid'ah.

Sunan Bonang (1465 M - 1525 M). Dianggap sebagai pencipta gending pertama dalam rangka mengembangkan ajaran Islam di pesisir utara Jawa Timur. Ia adalah putra Raden Rachmat dari perkawinannya dengan Dewi Candrawati dan merupakan saudara sepupu Sunan Kalijaga. Ia terkenal dengan nama Raden Maulana Makhdum Ibrahim, atau Raden Ibrahim (Makhdum adalah gelar yang biasa diberikan kepada seorang ulama besar di Hindia, dan berarti orang yang dihormati). Dari perkawinannya dengan Dewi Hiroh, ia memperoleh seorang putri bernama Dewi Rukhil yang kemudian diperistri Sunan Kudus.

Setelah belajar Islam di Pasai, Aceh, Sunan Bonang kembali ke Tuban, Jawa Timur, untuk mendirikan pondok pesantren. Santri-santri yang menjadi muridnya berdatangan dari berbagai derah Nusantara. Setelah Sunan Ampel wafat, pesantren yang ditinggalkannya tidak lagi mempunyai pemimpin resmi. Maka untuk mengisi kekosongan itu Sunan Bonang memprakarsai musyawarah para wali untuk membicarakan siapa yang akan memimpin pesantren tersebut. Hasil musyawarah wali memutuskan untuk mengangkat Raden Fatah menjadi pengganti almarhum Sunan Ampel.

Sunan Bonang dan para wali lainnya dalam menyebarkan agama Islam selalu menyesuaikan diri dengan corak kebudayaan masyarakat Jawa yang sangat menggemari wayang serta musik gamelan. Mereka memanfaatkan pertunjukan tradisional itu sebagai media dakwah Islam, dengan menyisipkan nafas Islam ke dalamnya. Syair lagu gamelan ciptaan para wali tersebut berisi pesan tauhid, sikap menyembah Allah SWT, dan tidak menyekutukan-Nya. Setiap bait lagu diselingi dengan syahadatain (ucapan dua kalimat syahadat); gamelan yang mengiringinya kini dikenal dengan istilah sekaten, yang berasal dari syahadatain. Sunan Bonang sendiri menciptakan lagu yang dikenal dengan tembang durma, sejenis mecapat yang melukiskan suasana tegang, bengis, dan penuh amarah.

Kegiatan dakwah Sunan Bonang dipusatkan di sekitar Jawa Timur, terutama daerah Tuban, dengan basis pesantren sebagai wadah mendidik kader. Dalam aktivitas dakwahnya, ia mengganti nama dewadewa dengan nama malaikat dalam Islam dengan maksud agar penganut Hindu dan Budha mudah diajak masuk agama Islam.

Sunan Bonang memberikan pendidikan Islam secara mendalam kepada Raden Fatah, putra raja Majapahit Prabu Brawijaya V, yang 
kemudian menjadi sultan pertama Demak. Catatan-catatan pendidikan tersebut kini dikenal dengan "Suluk Sunan Bonang" atau "Primbon Sunan Bonang". Isi buku tersebut berbentuk prosa ala Jawa Tengah, kalimatnya sangat banyak dipengaruhi bahasa Arab, dan sampai sekarang antara lain masih tersimpan di Universitas Leiden, Negeri Belanda.

Sunan Giri (Blambangan, pertengahan abad ke-15, awal abad ke16). Nama aslinya Raden Paku, disebut juga Prabu Satmata, dan kadangkadang disebut Sultan Abdul Fakih. Ia adalah putra dari Maulana Ishak, yang ditugaskan Sunan Ampel untuk mengembangkan agama Islam di Blambangan. Salah seorang saudaranya juga termasuk Wali Songo, yaitu Raden Abdul Kadir (Sunan Gunung Jati), dan ia mempunyai hubungan keluarga dengan Raden Fatah, karena istri mereka bersaudara.

Karena ayahnya, Maulana Ishak, ketika melaksanakan tugas menyebarkan agama Islam di Blambangan, pergi memperdalam ilmu ke Pasai dan tidak kembali lagi ke Jawa, Raden Paku diangkat anak oleh seorang wanita kaya bernama Nyai Gede Maloka, yang dalam Babad Tanah Jawa disebut Nyai Angeng atau Nyai Ageng Tandes. Ketika usianya beranjak dewasa, Raden Paku belajar agama di Pondok Pesantren Ampel Denta (pimpinan Sunan Ampel), dan di sana berteman baik dengan Raden Maulana Malik Ibrahim, putra Sunan Ampel, yang kemudian terkenal dengan Sunan Bonang. Dalam suatu perjalanan ibadah haji menuju ke Mekah, kedua santri ini lebih dahulu memperdalam pengetahuan di Pasai, yang ketika itu menjadi tempat berkembangnya ilmu ketuhanan, keimanan, dan tasawuf. Di sini Raden Paku sampai pada tingkat ilmu laduni, sehingga gurunya menganugerahinya gelar Ain al-Yaqin. Karena itulah ia kadang-kadang dikenal masyarakat dengan sebutan Raden Ainul Yakin.

Sunan Giri memulai aktivitas dakwahnya di daerah Giri dan sekitarnya dengan mendirikan pesantren, yang santrinya banyak berasal dari golongan masyarakat ekonomi lemah. Ia mengirim juru dakwah terdidik ke berbagai daerah di luar Pulau Jawa, yaitu Madura, Bawean, Kangean, Ternate, dan Tidore. Kegiatan-kegiatan ini menjadikan pesantren yang dipimpinnya menjadi terkenal di seluruh Nusantara.

Sunan Giri terkenal sebagai pendidik yang berjiwa demokratis. Ia mendidik anak-anak melalui berbagai permainan yang berjiwa agama, misalnya Jelungan, Jamuran, Gendi Ferit, Jor, Gula Ganti, Cublak-cubla Suweng, Ilir-ilir, dan sebagainya. Ia juga dipandang sebagai orang yang sangat berpengaruh terhadap jalannya roda Kesultanan Demak Bintoro (Kesultanan Demak), sebab setiap kali muncul masalah penting yang 
harus diputuskan, wali yang lain selalu menantikan keputusan dan pertimbangannya.

Sunan Drajat (Ampel Denta, Surabaya, sekitar tahun 1470 Sedayu, Gresik, pertengahan abad ke-16). Nama aslinya Raden Kosim atau Syarifuddin, tetapi karena ia dimakamkan di daerah Sedayu, maka kebanyakan masyarakat awam mengenalnya sebagai Sunan Sedayu.

Menurut silsilah, Sunan Drajat adalah putra Sunan Ampel dari istri kedua bernama Dewi Candrawati. Ia mempunyai enam saudara seayah seibu, di antaranya Siti Syareat (istri Raden Usman Haji), Siti Mut,a'innah (istri Raden Muhsin), Siti Sofiah (istri Raden Ahmad, Sunan Malaka), dan Raden Maulana Makdum Ibrahim (Sunan Bonang). Di samping itu ia mempunyai dua orang saudara seaqyah lain ibu, yaitu Dewi Murtasiyah (istri Raden Fatah) dan Dewi Murtasimah (istri Raden Paku atau Sunan Giri). Istrinya sendiri, Dewi Sifiyah, adalah putri Sunan Gunung Jati.

Sunan Drajat turut serta dalam musyawarah para wali untuk memutuskan siapa yang menggantikan Sunan Ampel untuk memimpin pesantren Ampel Denta, dan ketika para wali memutuskan untuk mengadakan pendekatan kultural pada masyarakat Jawa dalam menyiarkan agama Islam, Sunan Drajat tidak ketinggalan untuk menciptakan tembang Jawa yang sampai saat ini masih banyak digemari masyarakat, yaitu tembang pangkur.

Hal yang paling menonjol dalam dakwah Sunan Drajat adalah perhatiannya sangat serius pada masalah-masalah sosial. Ia terkenal mempunyai jiwa sosial dan tema-tema dakwahnya selalu berorientasi pada kegotongroyongan. Ia selalu memberi pertolongan kepada umum, menyantun anak yatim dan fakir miskin sebagai suatu proyek sosial yang dianjurkan Agama Islam.

Sunan Kalijaga (akhir abad ke-14 pertengahan abad ke-15). Terkenal sebagai seorang wali yang beriiwa besar, berpandangan jauh, berpikiran tajam, intelek, serta berasal dari suku Jawa asli.

Nama Kalijaga konon berasal dari rangkaian bahasa Arab qadi zaka yang berarti pelaksana dan membersihkan. Qadizaka yang kemudian menurut lidah dan ejaan menjadi Kalijaga berarti pemimpin atau pelaksana yang menegakkan kebersihan atau kesucian.

Sunan kalijaga bernama asli Raden Mas Syahid dan kadang-kadag djuluki Syekh Malaya. Ayahnya bernama Raden Sahur Tumenggung Wilatikta yang menjadi bupati Tuban, sedang ibunya bernama Dewi Nawang Ru. 
Daerah operasi dakwa Sunan Kalijaga tidak terbatas, bahkan sebagai mubaligh ia berkeliling dari satu daerah ke daerah lain. Karena sistem dakwahnya yang intelek dan aktual, maka para bangsawan dan cendekiawan sangat simpati terhadapnya, demikian juga lapisan masyarakat awam, bahkan penguasa.

Dalam melaksanakan pemerintahan Kesultanan Demak Bintoro, Raden Fatah sangat menghargai berbagai nasihat dan petunjuk Sunan Kalijaga. Dalam pemerintahan Demak, di samping sebagai ulama dan juru dakwah, Sunan Kalijaga juga penasihat Kesultanan Demak Bintoro. Ketika para wali memutuskan untuk mempergunakan pendekatan kultural terhadap masyarakat, termasuk di antaranya pemanfaatan wayang dan gamelan sebagai media dakwah, maka orang yang paling berjasa dalam hal ini adalah Sunan Kalijaga. Atas jasa-jasanya, Raden Fatah sebagai penguasa Kesultanan Demak Bintoro menghadiahkan sebidang tanah di sebelah tenggara Demak sebagai desa perdikan (bekas pajak) yang diperuntukkan bagi wahli waris dan keturunan Sunan Kalijaga.

Sunan Kalijaga juga sangat berjasa dalam perkembangan wayang purwa atau wayang kulit yang bercorak Islami seperti sekarang ini. Ia mengarang aneka cerita wayang yang bernafaskan Islam, terhadap wayang digunakannya sebagai sarana untuk menarik mereka masuk Islam.

Jasa Sunan Kalijaga terhadap kesenian bukan hanya terlihat pada wayang dan gamelan, tetapi juga dalam seni suara, seni uki, seni busana, seni pahat, dan kesusastraan. Banyak corak batik yang oleh Sunan Kalijaga diberi motif burung. Burung dalam bahasa Kawi disebut kulula. Kata tersebut ditulis dalam bahasa Arab menjadi qu dan qila yang berarti "perihalah ucapanmu sebaik-baiknya", dan menjadi salah satu ajaran etik Sunan Kalijaga melalui corak batik.

Sunan Kudus (abad ke-15-Kudus, 1550). Nama aslinya Ja'far Sadiq, tetapi sewaktu kecil dipanggil Raden Undung. Kadang-kadang ia dipanggil dengan Raden Amir Haji, sebab ketika menunaikan ibadah haji ia bertindak sebagai pimpinan rombongan (amir).

Sunan Kudus adalah putra Raden Usman Haji, yang menyiarkan Islam di daerah Jipang Panolan, Blora. Menurut silsilahnya Sunan Kudus masih mempunyai hubungan keturunan dengan Nabi Muhammad SAW. Silsilah selengkapnya: Ja'far Sadiq bin Raden Usman Haji bin Raja Pendeta bin Ibrahim as-Samarkandi bin Maulana Muhammad Jumadalkubra bin Zaini al-Husein bin Zaini al-Kubra bin Zainul Alim bin Zainul Abidin bin Sayid Husein bin Ali RA. 
Sunan Kudus menyiarkan agama Islam di daerah Kudus dan sekitarnya, dan dia memiliki keahlian khusus dalam bidang ilmu agama, terutama dalam ilmu fikih, usul fikih, tauhid, hadis, tafsir serta logika. Karena itulah di antara Wali Songo hanya ia yang mendapat julukan sebagai wali al-'ilmi (orang yang luas ilmunya), dan karena keluasan ilmunya ia didatangi oleh banyak penuntut ilmu dari berbagai daerah di Nusantara.

Di samping menjadi juru dakwah, Sunan Kudus juga menjadi panglima perang Kesultanan Demak Bintoro yang tangguh, dan dipercaya untuk mengendalikan pemerintahan di daerah Kudus, sehingga ia menjadi pemimpin pemerintahan sekaligus pemimpin agama di daerah tersebut.

Ada cerita yang mengatakan bahwa Suna Kudus pernah belajar di Baitulmakdis, Palestina, dan pernah berjasa memberantas penyakit yang menelan banyak korban Palestina ia diberi ijazah wilayah (daerah kekuasaan) di Palestina, namun Sunan Kudus mengharapkan hadiah tersebut dipindahkan ke Pulau Jawa, dan oleh Amir (penguasa setempat) permintaan itu dikabulkan. Sekembalinya ke Jawa ia mendirika masjid di daerah Loran tahun 1549; masjid itu nama Masjid Al-Aqsa atau ALManar (Masjid Menara Kudus) dan daerah sekitarnya diganti dengan kudus, diambil nama sebuah kota di Palestina, al-Quds.

Dalam melaksanakan dakwah dengan pendekatan kultural, Sunan Kudus menciptakan berbagai cerita keagamaan. Yang paling terkenal adalah Gending Maskumambang dan Mijil.

Sunan Muria (abad ke-15 abad ke-16). Salah seorang Wali Songo yang banyak berjasa dalam menyiarkan agama Islam di pedesaan Pulau Jawa. Ia adalah Putra Sunan Kalijaga. Nama aslinya Raden Umar Said, atau Raden Said, sedang nama kecilnya adalah Raden Prawoto, namun ia lebih terkenal dengan nama Sunan Muria karena pusat kegiatan dakwahnya dan makamnya terletak di Gunung Muria $(18 \mathrm{~km}$ di sebelah utara kota Kudus sekarang).

Ciri Khas Sunan Muria dalam upaya menyiarkan agama Islam adalah menjadikan desa-desa terpencil sebagai tempat operasinya. Ia lebih suka menyendiri dan bertempat tinggal di desa dan bergaul dengan rakyat biasa. Ia mendidik rakyat di sekitar Gunung Muria. Cara yang ditempuhnya dalam menyiarkan agama Islam adalah dengan mengadakan kursus-kursus bagi kaum pedagang, para nelayan, dan rakyat biasa.

Sunan Muria juga dikenal sebagai pendukung setia Kesultanan Demak Bintoro dan berperan serta dalam mendirikan Masjid Demak. 
Dalam rangka dakwah melalui budaya ia menciptakan tembang dakwah Sinom dan Kinanti.

Sunan Gunung Jati (Mekah), 1448-Gunung Jati, Cirebon Jawa Barat, 1570). Salah seorang dari Wali Songo yang banyak berjasa dalam menyebarkan Islam di Pulau Jawa, terutama di daerah Jawa Barat; juga pendiri Kesultanan Cirebon. Nama aslinya Syarif Hidayatullah. Dialah pendiri dinasti raja-raja Cirebon dan kemudian juga Banten.

Sunan Gunung Jati adalah cucu Pajajaran Prabu Siliwangi. Dari perkawinan Prabu Siliwangi dengan Nyai Subang Larang, lahirlah dua putra dan satu putri, masing-masing bernama Raden Walangsungsang, Nyai Lara Santang, dan raja Sengara.

Setelah Nyai Subang Larang wafat, raden Walangsungsang keluar dari kraton. Tidak lama setelah itu adik perempuannya menyusul. Keduanya belajar agama Islam kepada Syekh Datu Kahf (Syekh Nurul Jati) di Gunung Ngamparan Jati. Setelah 3 Tahun Belajar, mereka diperintahkan gurunya untuk naik haji ke Mekah. Di Mekah, Nyai Lara Santang mendapat jodoh, yaitu Maulana Sultan Mahmud (Syarif Abdullah), seorang bangsawan Arab yang berasal dari bani Hasyim.

Setelah menunaikan ibadah haji, Raden Walangsungsang kembali ke Jawa dan menjadi juru labuhan di Pasambangan, yang kemudian berkembang menjadi Cirebon. Sementara itu, Nyai Lara Santang melahirkan Syarif Hidayatullah memilih berdakwah ke Jawa daripada menetap di tanah Arab. Dia kemudian menemui Raden Walangsungsang yang sudah bergelar Pangeran Cakrabuana. Setelah pamannya itu wafat, ia menggantikan kedudukannya dan kemudian berhasil meningkatkan status Cirebon menjadi sebuah kesultanan. Ia kemudian terkenal dengan gelar Sunan Gunung Jati.

Setelah Cirebon resmi berdiri sebagai sebuah kerajaan Islam yang bebas dari kekuasaan Pajajaran, Sunan Gunung Jati berusaha mempengaruhi kerajaan yang belum menganut agama Islam itu. Dari cirebon, ia mengembangkan agama Islam ke daerah-daerah lain di Jawa Barat, seperti Majalengka, Kuningan, Kawali (Galuh), Sunda Kelapa, dan Banteng. Ia meletakkan dasar bagi pengembangan Islam dan perdagangan orang-orang Islam di Banten pada tahun 1525 atau 1526. Ketika ia kembal ke Cirebon, Banten diserahkan kepada anaknya, Sultan Maulana Hasanudin yang kemudian menurunkan raja-raja Banten. Di tangan raja-raja Banten inilah kemudia Kerajaan Pajajaran dikalahkan. Atas prakarsa Sunan Gunung Jati juga penyerangan ke Sunda Kelapa dilakukan pada tahun 1527. Penyerangan ini dipimpin oleh Faletehan atau Fatahillah (w. 1570), panglima perang Kerajaan Demak dan menantu Sunan Gunung Jati. 
Menurut Purwaka Caruban Nagari, sebagaimana dikutip oleh Ensiklopedi Islam, Sunan gunung Jati sebagai salah seorang wali songo, mendapat penghormatan dari raja-raja lain di Jawa, seperti kerajaan Demak dan Pajang. Karena kedudukannya sebagai raja dan ulama, ia di beri gelar Raja Pandita. Setelah Sunan Gunung Jati wafat, Cirebon mengalami pasang Surut. Kendati demikian, peran histories keagamaan yang dijalankannya tak pernah hilang. ${ }^{37}$

\section{Benarkah Wali Songo ada?}

Banyak kisah wali songo yang penuh dengan mistik. Banyak penulis, tukang cerita, dan para pembaca terbawa dalam kisah-kisah dengan analisis yang tidak memenuhi syarat keilmuan, tanpa didukung dengan sumber yang jelas, dipenuhi dengan hal-hal yang tidak masuk akal bahkan bertentangan dengan aqidah Islam. Salah satunya sebagaimana diceritakan oleh Syamsudduha dalam buku $W$ ali Songo take pernah ada? dan Azhar Arsyad dalam buku menjadi Indonesia.

Menurut Azhar Arsyad, Dalam catatan sejarah Jawa mengatakan bahwa Islam diwilayah ini didakwahkan oleh wali songo. Kesembilan juru dakwah ini oleh orang-orang Jawa dipandang sebagai orang suci dengan panggilan wali, kekasih Allah. Orang-orang Jawa biasa menulis atau menceritakan kisah para wali ini dengan bahasa yang indah dan penuh hormat serta dengan uraian tentang peristiwa-peristiwa di luar kebiasaan yang mereka alami. Diantara kisah tersebut adalah salah seorang dari wali ini mampu mengubah sebuah selop dari tanah liat menjadi emas ketika hendak mengislamkan seorang penguasa di Semarang. Wali lainnya mengubah beras menjadi pasir untuk memberi hukuman bagi penjual beras yang tidak jujur. Ada pula wali yang dikisahkan mampu berjalan di atas laut utara pulau Jawa, sementara wali lainnya mampu menyembuhkan seorang gadis yang berpenyakit kusta. ${ }^{38}$ Ada juga, wali yang bisa berubah menjadi cacing, menyeberang lautan dengan tiga langkah ${ }^{39}$ dan lain sebagainnya.

Bahkan Prof. Slamet Mulyana, dalam buku Runtuhnya Kerajaan Hindu-Jawa dan timbulnya Negara-negara Islam di Nusantara, menyebut bahwa sebagian wali songo berasal dari negeri Cina. Dalam kesimpulan yang ditulis Slamet, Bong Swi Hoo - yang datang ke Jawa tahun 1445 sama dengan Sunan Ampel. Bong Swi Hoo ini menikah

\footnotetext{
${ }^{37}$ Lihat Ensiklopedi Islam, hal 173-184.

${ }^{38}$ Lihat Menjadi Indonesia, hal 93.

${ }^{39}$ Lihat majalah al-Furqan, Ritual Ziarah Wali Songo dalam Sorotan, edisi AprilMei 2008, hal 22
} 
dengan Ni Gede Manila yang merupakan anak Gan Eng Cu (mantan kapiten Cina di Manila yang dipindahkan ke tuban pada tahun 1423). Dari perkawinan ini lahir Sunan Bonang. Sunan Bonang di asuh oleh Sunan Ampel bersama dengan Sunan Giri. ${ }^{40}$

Slamet pun menyebutkan bahwa sunan Kalijaga yang masa mudanya bernama Raden Said itu tak lain dari Gan Si Can. Sedangkan sunan Gunung Jati atau Syarif Hidayatullah menurutnya tidak lain adalah Toh A Bo, Putra Sultan Trenggana (Memerintah di Demak tahun 1521-1546). Sementara sunan Kudus atau Ja'far Sidik yang tidak lain adalah Ja Tik Su. ${ }^{41}$

Para penulis dan pengagum wali songo sebernarnya tidak dapat menjawab dengan yakin bahwa para wali songo itu memang ada atau hanya cerita turun-temurun dari nenek moyang mereka?.

Bahkan kalau kita mau meneliti tulisan-tulisan yang dibukukan tentang wali songo, ada beberapa naskah asli tentang keberadaan wali songo, justru menyebutkan jumlahnya tidak sampai sembilan, melainkan lima belas orang, sehingga penyebutan wali songo yang berjumlah sembilan tenyata 'tidak baku' atau dengan kata lain sangat meragukan.

Silsilah wali songo versi Jawa telah ditulis oleh banyak penulis berbeda dalam tulisannya, karena memang sumber aslinya tidak lain adalah cerita lisan, sehingga keabsahannya pun masih dipertanyakan. ${ }^{42}$

Ada pula yang menyebut bahwa nama wali songo itu bukan hanya itu-itu saja walinya, tapi seperti sebuah dewan ketika seorang wali itu meninggal digantikan dengan wali yang lain sehingga jumlahnya tetap sembilan - wali songo.

Sekarang ini yang harus dilakukan oleh para sejarawan Islam Indonesia menemukan riteratur yang jelas dan benar tentang wali Songo untuk membuktikan keberadaan dan perannya dalam pengislaman di tanah Jawa.

\section{Islam Agama Mayoritas}

Setelah Islam masuk dan berkembang di Nusantara dengan subur dan berjalan damai dan cepat. Hal ini dikarenakan dari antusiasnya masyarakat Indonesia menerima Islam sebagai agama baru mereka,

\footnotetext{
${ }^{40}$ Prof. Slamet Mulyana, Runtuhnya Kerajaan Hindu-Jawa dan timbulnya Negaranegara Islam di Nusantara, (Yogyakarta: LkiS, Juni 2007), hal ix.

${ }^{41}$ Prof. Slamet Mulyana, Runtuhnya Kerajaan Hindu-Jawa dan timbulnya Negaranegara Islam di Nusantara, Ibid, hal x.

${ }^{42}$ Majalah al-Furqan, Ibid, hal 22.
}

97 | Bina Ummat | Vol 4 | No. 1 | 2021 
maka tidak sedikit orang-orang Indonesia saat itu yang berhasrat hendak mempelajari Islam di tempat asalnya.

Tengku Ismail Jakub menceritakan bahwa kebiasaan mengarungi lautan membawa hasil bumi Indonesia ke luar negeri, sekarang dialihkan pula untuk menuntut ilmu agama. Mereka berlayar ke Tiongkok, berjumpa di sana dengan orang-orang Islam dari tanah Arab, ke Hindustan, ke laut Merah, Yaman dan Mekah, lalu menuntut ilmu di sana. $^{43}$

Ada pula putra Indonesia yang kemudian bermukim di sana bertahun-tahun lamanya. Ada pula yang menetap dan tidak pulang lagi ke Indonesia, menjadi guru di Aden dan tanah Arab. Seperti Abu Mas'ud Abdullah bin Mas'ud al-Jawi, Syaikh Abdurrauf al-Fanshury, ulama besar di zaman Iskandar Muda Mahkota Alam, 19 tahun lamanya belajar di kota Mekah dan Madinah.

Dan tidak sedikit mereka yang kemudian hari menjadi ulamaulama besar dan menyampaikan Islam untuk bangsanya, menjadi panutan masyarakat Islam Indonesia pada umumnya. Maka jadilah Islam menjadi agama mayoritas bangsa Indonesia. Dalam perkembangan peng-Islam-an selanjutnya bangsa Indonesia aktif mengambil peran dan memegang pimpinan. ${ }^{44}$

Kedatangan Islam di Nusantara membawa kecerdasan dan peradaban yang tinggi dalam membentuk kepribadian bangsa Indonesia. Dari tempat pesisir tepi pantai, pengaruh Islam berkembang dan meluas dan pada akhirnya menjelma menjadi masyarakat yang kuat.

Sebagai bukti dari kenyataan sejarah ini, Islam dan kaum muslim bisa berjuang dan memperoleh kemerdekaan Indonesia. Semua itu merupakan indikasi bahwa Islam dapat menumbuhkan masyarakat Indonesia menjadi bangsa yang kuat dan berperadaban maju.

\section{Perkembangan Islam di Indonesia}

Kedatangan Islam di berbagai daerah Indonesia tidaklah bersama. Demikian pula kerajaan-kerajaan dan daerah yang didatanginya mempunyai situasi politik dan sosial budaya yang berlainan. Pada waktu kerajaan Sriwijaya mengembangkan kekuasaannya pada sekitar abad ke tujuh dan ke delapan, Selat Malaka sudah mulai dilalui oleh para pedagang muslim dalam pelayarannya ke negeri-negeri di Asia Tenggara dan Asia Timur. Berdasarkan berita Cina zaman T’ang, pada abad-abad

${ }^{43}$ Ismail Jakub, Sejarah Islam di Indonesia, Ibid, hal 18

${ }^{44}$ Ismail Jakub, Ibid, hal 18. 
tersebut diduga masyarakat muslim telah ada, baik di Kanfu (Kanton) maupun di daerah Sumatera Sendiri. Perkembangan pelayanan dan perdagangan yang bersifat internasional antara negeri-negeri di Asia bagian barat dan timur mungkin disebabkan oleh kegiatan kerajaan Islam di bawah Bani Umayyah di bagian barat maupun kerajaan Cina zaman dinasti T'ang di Asia Timur serta kerajaan 'Sriwijaya di Asia Tenggara. Adalah suatu kemungkinan bahwa menjelang abad ke sepuluh para pedagang Islam telah menetap di pusat-pusat perdagangan yang penting di kepulauan Indonesia, terutama di pulau-pulau yang terletak di selat Malaka, terusan sempit dalam rute pelayaran laut dari negeri-negeri Islam ke Cin. Tiga abad kemudian menurut dokumen-dokumen sejarah tertua, pemukiman orang-orang Islam didirikandi Perlak dan Samudera Pasai di timur laut pantai Sumatera.

Saudagar-saudagar Arab dari Arab selatan semenanjung tanah Arab yang melakukan perdagangan ke tanah Melayu sekitar $630 \mathrm{M}$ (tahun ke sembilan Hijriyyah). telah banyak yang memeluk Islam. Hal itu membuktikan bahwa Islam telah masuk ke Indonesia sejak abadabad pertama Hijriyyah, atau sekitar abad ke tujuh dan ke delapan Masehi yang dibawa langsung oleh para saudagar dari Arab. Dengan demikian dakwah Islam telah tiba di tanah Melayu sekitar tahun $630 \mathrm{M}$, takala zaman hidup Nabi Muhammad SAW. Keterangan lebih lanjut tentang masuknya Islam ke Indonesia ditemukan pada berita dari Marcopolo, dimana dalam tahun 1292 ia pernah singgah di bagian utara daerah Aceh dalam perjalannya dari Tiongkok ke Persia melalui jalan laut. Di Perlak ia menjumpai penduduk yang telah memeluk Islam dan banyak pedagang Islam dari Hindia yang giat menyebarkan agama itu.

Para pedagang muslim menjadi pendukung daerah-daerah Islam yang muncul kemudian, dan daerah yang menyatakan dirinya sebagai kerajaan yang bercorak Islam ialah Samudera Pasai di pesisir timur laut Aceh. Munculnya daerah tersebut sebagai kerajaan Islam yang pertama diperkirakan mulai abad ke 13. Hal itu dimungkinkan dari hasil proses Islamisasi di daerah-daerah pantai yang pernah disinggahi para pedagang muslim sejak abad ke tujuh.

Sultan yang pertama dari kerajaan Islam Samudera Pasai adalah Sultan Malik Al-saleh yang memerintahkan pada tahun 1292 hingga 1297. Sultan ini kemudian digantikan oleh puterannya yang bernama Sultan Muhammad Malik Az-Zahir sejak 1297 hingga 1326. Pada masa pemerintahan Sultan yang ketiga, yakni Sultan Mahmud Malik Az-zahir, kerajaan Islam Samudera pasai menjadi pusat studi agama Islam dan merupakan tempat berkumpul para ulama Islam dari berbagai negara Islam untuk berdiskusi tentang masalah-masalah keagamaan dan 
keduniawian. Berdasarkan berita dari Ibnu Batutah, seorang pengembara asal Maroko yang mengunjung Samudera pada 1345, dikabarkan bahwa pada waktu ia mengunjungi kerajaan itu, Samudera Psai berada pada puncak kejayaannya. Dari catatan lain yang ditinggalkan Ibn Batutah dapat diketahui bahwa pada masa itu kerajaan Samudera Pasai merupakan pelabuhan yang sangat penting, tempat kapal-kapal dagang dari Tiongkok dan India serta dari tempat-tempat lain di Indonesia, singgah dan bertemu untuk memuat dan membongkar barang-barang dagangannya.

Kerajaan Samudera Pasai makin berkembang, baik di bidang politik maupun perdagangan dan pelayaran, di samping agama Islam. Hubungan dengan Malaka makin ramai, sehingga di Malaka pun sejak abad ke XIV timbul corak masyarakat muslim. Perkembangan masyarakat muslim di Malaka makin lama makin meluas, dan akhirnya pada awal abad ke 15 berdiri kerajaan islam Malaka. Hal itu disebabkan oleh karena kemajuan Malaka dalam bidang pelayaran dan perdagangan beserta kemajuan dalam bidang kegiatan keagamaan (Islam). Penguasa kerajaan, meskipun belum memeluk Islam, dengan senang hati menerima kedatangan mereka. Para penganut agama Islam diberi hakhak istimewa, bahkan untuk mereka telah dibangun sebuah masjid. Para pedagang yang singgah di Malaka kemudian banyak yang memeluk Islam dan menjadi penyebar agama Islam ke seluruh kepulauan Nusantara dimana mereka mengadakan transaksi perdagangan.

Kerajaan Malaka yang pertama kali didirikan oleh Paramisora awal, abad ke 15, yang menurut cerita sesaat sebelum meninggal dalam tahun 1414, Paramisora masuk Islam kemudian berganti nama menjadi Iskandar Syah, dikembangkan oleh puteranya yang bernama Muhammad Iskandar Syah adalah Sultan Mudzafar Syah (1445-1458), di bawah pemerintahannya Malaka menjadi pusat perdagangan antara timur dan barat, dengan kemajuan-kemajuan yang sangat pesat sehingga jauh meninggalkan Samudera Pasai. Usaha mengembangkan Malaka hingga mencapai puncak kejayaannya dilakukan oleh Sultan Mansyur Syah (1458-1477) sampai masa pemerintahan Sultan Alaudin Syah (1477-1488).

Sementara itu kedatangan pengaruh Islam ke wilayah Indonesia bagian timur (Sulawesi dan Maluku), tidak dapat dipisahkan dari jalur perdagangan yang terbentang antara pusat lalu lintas pelayaran internasional di Malaka, Jawa dan Maluku. Menurut tradisi setempat, sejak abad ke 14, Islam telah sampai ke daerah Maluku, dimana disebutkan bahwa raja Ternate ke 12, Molomateya (1350-1357), 
bersahabat karib dengan orang Arab yang memberinya petunjuk dalam pembuatan kapal, tetapi agaknya bukan dalam kepercayaan.

Pada masa pemerintahan Marhum di Ternate, datanglah seorang raja dari Jawa bernama Maulana Husain yang menunjukkan kemahiran menulis huruf Arab yang 'ajaib' seperti yang tertulis dalam Al-Qur'an. Hal ini sangat menarik hati Marhum dan orang-orang di Maluku. Kemudian ia diminta oleh mereka agar mau mengajarkan huruf-huruf yang indah itu. Sebaliknya permintaan Maulana Malik adalah agar mereka tidak hanya mempelajari agama Islam. Demikianlah Maulana Husayn berhasil meng-Islamkan orang-orang Maluku. Raja Ternate yang dianggap benar-benar memeluk agama Islam adalah Zainal Abidin (1486-1500).

Dari ke tiga pusat kegiatan Islam itulah maka Islam menyebar dan meluas memasuki pelosok-pelosok kepulauan Nusantara. Penyebaran yang nyata terjadi dalam abad ke 16. Dari Malaka daerah-daerah Kampar, Indragiri dan Riau menjadi Islam. Dari Aceh Islam meluas sampai ke Minangkabau, Bengkulu dan Jambi. Di mulai dari Demak maka sebagian terbesar pulau jawa menjadi Islam. Banten yang diislamkan oleh Dema meluaskan dan menyebarkan Islam ke Sumatera Selatan. Di Kalimantan, kerajaan Brunei, yang dalam abad ke 16 menjadi Islam, meluaskan penyebaran Islam di bagian Barat Kalimantan dan Filipina. Sedangkan Kalimantan selatan mendapatkan pengaruh Islamnya dari tanah jawa. Dari Ternate Islam meluas meliputi pulaupulau di seluruh Maluku serta daerah pantai timur Sulawesi. Dalam abad ke 16 di Sulawesi abad ke 16 dapat dikatakan bahwa Islam telah tersebar dan mulai meresapkan akar-akarnya di seluruh Nusantara ${ }^{45}$.

\section{KESIMPULAN}

Banyak teori tentang masuknya Islam di Indonesia yang dijelaskan oleh para ahli-ahli Islam dan Barat. Dan tidak sedikit dari mereka sarjana-sarjana Islam ahli sejarah itu yang menyandarkan teorinya kepada para orientalis Barat. Inilah yang kemudian hari menjadi polemik dan perdebatan tentang Islam di Indonesia.

Tidak sedikit diantara sarjana-sarjana Islam Indonesia yang berusaha meluruskan polemik itu. Dan kemudian menunjukan buktibukti kepada masyarkat Intelektual Islam bahwa Islam datang pada permulaan abad pertama hijriyah, dan langsung dari Mekah dan

\footnotetext{
${ }^{45}$ Dadan Wildan, hal 5-9.
} 
Madinah. Bukan dugaan para orientalis bahwa Islam datang pada abad ke 12 atau $13 \mathrm{M}$.

Dan sebagian sarjana-sarjana Islam ahli sejarah itu menyebutkan bahwa pembawa Islam ke Nusantara ini di sampaikan oleh para dai, atau para sudagar Islam yang disertai dengan para dai. Ini yang menjadi keteguhan pandangan dari Haji Agus Salim, KH. Saefuddin Zuhri, Hamka dan yang lainnya.

Sarjana-sarjana dan intelektual Islam ahli sejarah ini menjelaskan pula bahwa Islam berkembang di Nusantara dengan damai tanpa kekerasan. Sehingga mendapat sambutan yang baik dari masyarakat setempat, dan berkembang dengan cepat. Yang masuk dan memeluk Islam di Nusantara ketika Islam datang itu tidaknya rakyat jelata, tetapi juga dari kaum keraton dan bangsawan.

Setelah lama Islam bersentuhan dengan penduduk Indonesia, lama kelamaan karena faktor Islam sendiri dan juga, pembawanya. Maka Islam lambat laun menjadi agama mayoritas bangsa Indonesia.

Dalam catatan sejarah Jawa mengatakan bahwa Islam diwilayah ini didakwahkan oleh wali songo. Kesembilan juru dakwah ini oleh orang-orang Jawa dipandang sebagai orang suci dengan panggilan wali, kekasih Allah. Orang-orang Jawa biasa menulis atau menceritakan kisah para wali ini dengan bahasa yang indah dan penuh hormat serta dengan uraian tentang peristiwa-peristiwa di luar kebiasaan yang mereka alami. Diantara kisah tersebut adalah salah seorang dari wali ini mampu mengubah sebuah selop dari tanah liat menjadi emas ketika hendak mengislamkan seorang penguasa di Semarang. Wali lainnya mengubah beras menjadi pasir untuk memberi hukuman bagi penjual beras yang tidak jujur. Ada pula wali yang dikisahkan mampu berjalan di atas laut utara pulau Jawa, sementara wali lainnya mampu menyembuhkan seorang gadis yang berpenyakit kusta.

Kisah wali songo yang penuh dengan mistik. Banyak penulis, tukang cerita, dan para pembaca terbawa dalam kisah-kisah dengan analisis yang tidak memenuhi syarat keilmuan, tanpa didukung dengan sumber yang jelas, dipenuhi dengan hal-hal yang tidak masuk akal bahkan bertentangan dengan aqidah Islam.

Para penulis dan pengagum wali songo sebernarnya tidak dapat menjawab dengan yakin bahwa para wali songo itu memang ada atau hanya bersumber dari cerita yang sulit dibuktikan dengan sumber data yang jelas.

Silsilah wali songo versi Jawa telah ditulis oleh banyak penulis berbeda dalam tulisannya, karena memang sumber aslinya tidak lain 
adalah cerita lisan, sehingga keabsahannya pun masih mengundang misteri.

Ada pula yang menyebut bahwa nama wali songo itu bukan hanya itu-itu saja walinya. Tetapi, senantiasa berganti-ganti. Bila satu orang wali ada yang meninggal kemudian digantikan dengan wali yang lain, sehingga jumlahnya tetap sembilan - songo. Sehingga ada yang menyebut seperti sebuah dewan. Yang walinya bisa berganti-ganti.

\section{DAFTAR PUSTAKA}

A. Mu'in Umar (editor), Penulisan Sejarah Islam di Indonesia dalam Sorotan, Yogyakarta: 1985, Dua Dimensi. hal 23.

Al-Habib Alwi bin Thohir Al-Haddad, Sejarah Masuknya Islam di Timur Jauh, Jakarta: 1995, Lentera, cet. Ke-2.

Azyumardi Azra, Jaringan Ulama Timur Tengah dan Kepulauan Nusantara Abad XVII dan XVIII Melacak. Akar-akar Pembaharuan Pemikiran Islam Di Indonesia, Bandung, Mizan, Cet. Ke-4, Nopember 1989.

Dadan Wildan, Pentas Persis dalam sejarah Islam Indonesia, Persis, Bandung, tanpa tahun.

Endang Saifuddin Anshari, Wawasan Islam Pokok-pokok pikiran tentang paradigma dan Sistem Islam, Jakarta: Juni 2004, Gema Insani Press.

Ensiklopedi Islam, Jakarta: PT. Ichtiar Baru Van Hoeve, Cet. 1, 1993.

G.F. Pijper, Beberapa studi Tentang Sejarah Islam di Indonesia 1900-1950, Jakarta, UI, 1984.

Hadji Agus Salim, Riwajat Kedatangan Islam Di Indonesia, Jakarta: 1962, Tintamas.

Hamka, Prof. Dr. Sejarah Umat Islam, Singapura: Pustaka Nasional 2005, Cet. Ke-5.

Heri Nurdi, Risalah Islam Nusantara, Dalam topik Sejarah Emas Muslim Indonesia, Sabili, No. 9 tahun X 2003.

Ismail Jakub, Sejarah Islam di Indonesia,Jakarta: 1973, Widjaya, ct. Ke-3

KH. Saefuddin Zuhri, Sejarah Kebangkitan Islam dan Perkembangannya di Indonesia, Bandung: 1981, PT. al-Maarif Bandung, cet. ke-3.

Komaruddin Hidayat \& Ahmad Gaus AF (editor), Menjadi Indonesia 13 Abad Eksistensi Islam di Bumi Nusantara, Bandung, Mizan, Oktober 2006, Cet. 1. 
LWC. Van Den Berg, Hadramaut dan koloni Arab di Nusantara, Jakarta: INIS, 1989.

Masroer Ch. Jb., The History OfJava, Jakarta: Ar-Ruzz, 2004, Cet. 4.

Syarief Hidayat, Sejarah Masuknya Islam di Indonesia, makalah dari seminar Historiografi Islam Indonesia. 9-11 Desember 2007, Balitbang Lektur Keagamaan DEPAG RI.

Taufik Abdullah, Pemikiran Islam di Nusantara dalam Perspektif Sejarah, Prisma, 3 Maret 1991. 